\title{
Defensible Spaces and Home Ignition Zones of Wildland-Urban Interfaces in the Fire-prone Areas of the World ${ }^{\dagger}$
}

\author{
Shahriar Rahman ${ }^{1, *}$ and Sanzida Rahman ${ }^{2}$ \\ 1 Department of Earth and Environmental Sciences, Macquarie University; shahriar.rahman@mq.edu.au \\ 2 Department of Urban \& Regional Planning, Khulna University of Engineering \& Technology (KUET); \\ sanzidarahman.bd15@gmail.com \\ * Correspondence: shahriar.rahman@mq.edu.au; Tel.: +61-469746677.
}

\begin{abstract}
Wildland-Urban Interfaces (W-UI) are at high risk of wildfires. Defensible spaces and home ignition zones are the two main aspects to protect lives and livelihoods of W-UI in the United States, Canada and Australia. The different part of the world has different rules and regulations for W-UI land management. We have discussed the defensible spaces in fire-prone areas, current ignition zone distances from structures, building materials, architectural design, the fire resistance trees, ground cover, landscaping and some other precautions to save lives and assets in the prominent fire-prone zones for three different countries (United States, Canada and Australia) of the world.
\end{abstract}

Keywords: Defensible Space; Fire Resistance; Ignition Zone; Wildfire; Wildland.

\section{Introduction}

The wild-urban interface qualitatively as a place where human beings and their creation meet or intermingle with wildland resources [1]. This area belongs at high risk for wildfires which resulting in the destruction of homes and lives, the degradation of forests, the introduction of exotic species and the loss in biodiversity [1]. But, people enjoy visiting and living in natural settings like W-UI land; thus, it has a great demand for new houses and other developments [2]. These places are used not only for walking, cycling and picnicking but for living, in primary and second-hand homes [3]. This appealing beauty, however, hides a variety of possible threats, many landowners do not understand. The W-UI is extensive in the USA, Canada, Argentina, Greece, Australia, France, and South Africa [4-6]. Residential lots built in the WUI take up much more space than houses built in urban areas, a key feature of the W-UI, since low-density housing is more expensive to maintain. Other words, it is not only the number of homes but the per-acre land use per house that is of importance to calculate the cost of safeguarding houses against wildfires. Residential areas in the wild often occupy over twice the size of homes built elsewhere. Housing near forested areas is estimated in the west coverage of approximately 3 acres per residence, compared with an average of 1.1 acres per house on other western private lands [7].

The proximity of homes and wildland plants increases the risk of fire. As homes are built in the $\mathrm{W}$-UI, natural vegetation is lost, and degraded landscape producing non-native species and soils are disturbed, resulting in the spread of non-native species. In wildfires and many other environmental issues, understanding of W-UI patterns and W-UI growth is essential [4]. The W-UI is critical for resource managers because the existence of individuals and institutions in and around the forest affects both its resources and the social pressures they face in maintaining them. Residents are 
negatively and unequivocally affected by the fire in the W-UI. Just smoke, evacuation and interruption of everyday life will result if they are fortunate. Landowners can lose their houses in the wildfire. The W-UI is difficult and potentially dangerous for combating fire because burners are usually trained to fight structural or wildfires, but rarely both [8]. Climate change, construction and land management are increasing the risks associated with wildfires $[2,9,10]$. The W-UI will become increasingly important as more homes are built in W-UI areas and as fire activity increases due to climate change. The awareness of W-UI forest fires is important due to the possible effects on environmental, cultural, ecological and human community management [11].

Depending on the region of the country, fire branches might be referred to as wilderness fires, such as brown fire, forest fires, rangelands or anything else but they are all part of the W-UI [12]. Wildfires instigated by nature, such as lava or lightning, but humans cause most. Human-cause fires arise from unintentional campfires, scorching of scrap, neglected cigarettes, and deliberate acts of incense. Lightning is considered as natural fires where only two types are shown. First one is cold lightening and second is hot lightening. Cold lightning has short stroke comparatively but severe with intense electrical current. Hot lightning has fewer voltage currents, but they continue for more time. Fires usually begin with incredibly durable fire lightning bolts [13]. Due to the recent rises in both the amount of destructed and the areas destroyed annually by wildland fire, the W UI has received considerable attention [14]. The communities adjacent and in the wilderness are at varying risk from wildfires. Wildland fire has had an ever-growing, more frequent and far-reaching impact on communities. Increased W-UI development means increased wildfire risk and further abolition needs costing billions annually. An integrated preparation and mitigation strategy is an efficient way to tackle increased removal costs and reduce the risk to communities [15].

\section{Defensible Space}

Defensible space is one of the most cost-effective ways of protecting a house from wildfire and the property owner can often create it [16]. By reducing all type of fuel, the chance of fire spread should be minimized. The required defensible space is comprised of two areas-United States and Australia. Both areas are domestic security and the low fuel area [17].

\subsection{Zone 1 \# 30 feet from the house [16,18]:}

Within 30 feet from the houses or built structure is marked as zone-1. This portion is very sensitive and should be well protected by removing all fuel products like vegetation that is firefriendly, firewood stacks, wood furniture, umbrellas and wood cover. All dead plants, grass, weeds, dry leaves and pine needles must be cleared from the front side garden, deck and rain gutters. Dry debris is good fuel to spread fire thus roofs should be cleared before starting the fire season. Moreover, it is necessary to trim tree branches and distance should be maintained at least 10 feet from the branches. Ceiling and kitchen chimney must be 10 feet away from canopy trees. Removing plants and flammable tubes which is placed near the windows or prune them. Clear vegetation and objects from decks that can catch fire easily remove as early.

\subsection{Zone 2 \# 100 feet from the houses, buildings and decks [18]:}

Within 100 feet from the houses or built structure is marked as zone-2. To build a firebreak through the whole yard, using hardening features such as entrances and paved, gravel pathways or patios. Fireproof plant, low volume vegetation conserves well moisture and requires minimal 
support, such as the tailing of dead and dying trees. Single auxiliary buildings, such as a separate garage, pump room, pergola and appliances shed at least 50 meters away from home. Increasing the distance when the structure is used to store fuel. It must be followed by the rules with suggested methods for constructing auxiliary buildings with fire resistance. Make sure patio furniture is constructed from non-fuel materials like metal or at least 30 feet from the house. Replacing furniture from courtyard ensure safety from wildfire. Wood piles are stored in a vegetation-free zone as the gravel field, at least 30 feet from the building. Fuel tanks are held off a minimum distance from a structure needed by code or more and position them underground or on the non-fuel pad. Annual grass must be cut or mould down to 4 inches in height. Horizontal space must build in between trees and shrubs. The horizontal distance depends on the slope and height of the shrubbery or trees. It's ten feet flat to the slope of the mild slope (less than 20\%), is 20 feet mild to the slope of the severe slope (20\% $-40 \%)$, and 30 feet to the moderate slope (> $40 \%)$. Vertical distances are allowed between grass, shrubs and trees (remove each tree branch from the ground at least 6 feet). The fallen leaves, berries, twigs, wood, cones and little branches might be clean out but depth of 3 inches can be required.

\subsection{Zone 3:}

Decrease fuels farther than 100 feet from the house, horizontally and vertically as described above, by thinning and cutting vegetation. In Zone 3, trimming may be less than in Zone 2. The goal of Zone 3 is to improve wildlife health and to slow a wildfire. Therefore, Zone 3 reflects an esthetic transition from the more modified Zone 2 to the stable climate [16].

\section{Home Ignition Zone}

\subsection{United States:}

The circular area between 30-100 feet around a house is called the Home Ignition Zone (HIZ). The first 30 -feet field around a building in zone 1 . Zone 2 reflects the ground between 30 and 60 feet. Zone 3 covers the area around the house above 60 to 100 feet. Reduction of fire-fuels and proper arrangements of precautions are the only way to minimise risk, damage and loss during wildfires in these areas. So, it is important to walk out housing area looking for vulnerabilities [19]. For selecting building materials for roof and eaves, outer wall, adjacent trees, shrubs, and lawns, wooden decks and fences are very important for reducing fire incident and must be checked out carefully.

\section{Roof and eaves:}

Materials for roofing should be fire-free, such as the Fire Resistance fibreglass Asphalt Shingles, Metal, Clay tiles or concrete. It must be ensured that there are no missing shingles; no gaps; litter-free peaks, valleys, and gutters. Gutters should be leaves-free because leaf-filled drainages are one of the most vulnerable areas for the houses from wildfire. Closing the eaves in due time and flame protective materials or well painted (ply) wood should be used for the soffits. Flammable materials or well painted (ply) wood should be used for the soffits. Metallic and decorative attic vents should be used to line with fine mesh metal screening to resist heated coals. If a fire occurs, it could be maintained with painted wood products that can prevent wood grain to embers and ignited for hours.

Outer walls:

Flame-protective materials are brick, stone, stucco or mixed masonry which is recommended for outer wall decoration. If the natural wood grain is exposed to threaten for fire, it 
must be covered with paint, varnish or stain to reduce the chance of hidden heated coals. Windows with two panels can heat break but sometimes it becomes overheat and break, which allows the flame to reach inside of the house. Combustible material must be kept away from windows to prevent windows breaking. Litter and bird nests should be free from nooks and crannies. Embers can set the leaves and the litter on and produce sufficient heat for the wooden door to ignite.

Trees, shrubs, and lawns:

Overhanging and overlying tree limbs must be replaced. When trees leave droplet, gutters will be filled. Also, remove small branches that close to eaves. 6-10 feet from the ground cut down the lowest tree limbs so the climbing flames can not burn the trees. Shrub under trees are trimmed by cutting away, so it cannot catch fire dead or overgrown branches or stems. Structural walls are kept safe by removing shrubs around 10-12 feet from it. Shrubs must be removed from two to three feet below the windows of the house.

Most importantly, climbing or trailing plants must be kept away from the house, windows, arches of entry, porch swings, wooden fences and trellises. Well watered plants should be reserved for maintaining stems and trunks moist. Grass lawns must be trimmed and watered. Clear driveways must be set for serving it as a firebreak.

\section{Wooden Decks:}

Wooden deck is a part of the house if it's connected to it. Wooden decks must be in good condition with paint or finished stain in order not to expose the grain of the wood and considered using fire-resistant materials when replacing decks. The artificial logs should be removed from houses or decks at least 30 feet away. Always keep clean underneath the deck and fill it with sand and pebbles. Flammable (propane) must be held from the house or deck at least 30 feet apart. A piece of cloth or plastic fastened keeping in the front and backside of the houses so that seconds can be saved when the fire happens. Maintaining the wooden trellis with the desired finish and cushions from deck furniture must be removed after long periods have passed.

\section{Wooden fences:}

Wooden fences must be kept into the desired finish covering exposed grains of wood and slow weathering. Hold the vines away from the crest and cut grass to avoid interaction with wooden lattices. Also, split off the inside and outside of the timber fence. It must try to substitute wood for metal fencing. At least, if the wood fence touches the house, metal flashes will be used to separate the wall. A better way to connect the privacy fences in the property to the house is to use a metal fence.

Other considerations:

Besides all the factors mentioned above, some others must be considered as extra support for ignition. Separation of the crown is one of them. Cut down touching treetops to avoid spreading flames in treetops and try to reach 3-5 feet between the trees. Branches hanging over properties must be cut to reduce fire spread. Honour the cuttings size limits so vegetation is avoided on service days and does not waste cuttings in nearby woods. Trees threw downcast and dead-on wildland banks can quickly light up like fireplace logs. Wind speeds upsurge with the angle of a slope, which increases the risk of hilltops larger. People may get fined if entering neighbour-land on a restricted nature preserve or, worst case, someone home may be devastated by those dead and downcast fire 
logs while leaving away. It is most important to choose the right plants and materials which can resist fire [18]. Built fire-safe areas must be built with stone walls, courtyards, decks and roads. Soil, mulch, flower beds and gardens are used for bare spaces and fire breaks as ground cover. No 'fireproof' plants are available. Select high humidity plants near the soil that have a low content of sap and resin and fire retardant plants that are resistant to combustion, such as rock, ice and aloe. Pick fireproof shrubs like hedging roses, cobble shrub, currants, cotoneaster, sumacs, and apple shrub. Harrow, maple, poplar and cherry trees are not as inflammable as pines, firs, and other coniferous trees. In California fireproof plants are perfect as they are often resistant to drought.

Table 1: Suggested Fireproof Plants in Canifornia:

\begin{tabular}{|c|c|c|}
\hline Scientific Name & Common Name & Descriptions \\
\hline $\begin{array}{l}\text { Lavandula } \\
\text { stoechas }\end{array}$ & $\begin{array}{l}\text { French } \\
\text { Lavender }\end{array}$ & $\begin{array}{l}\text { It is a fireproof plant that thrives in dry conditions of } \\
\text { production. }\end{array}$ \\
\hline Mimulus rubellus & $\begin{array}{l}\text { Red Monkey } \\
\text { Flower }\end{array}$ & $\begin{array}{l}\text { This produces beautiful red and yellow flowers and tolerates } \\
\text { drought }\end{array}$ \\
\hline Epilobium canum & $\begin{array}{l}\text { California } \\
\text { Fuchsia }\end{array}$ & $\begin{array}{l}\text { These continuous flowers are fire-proof and require little or } \\
\text { no water }\end{array}$ \\
\hline Salvia officinalis & Sage & $\begin{array}{l}\text { These plants give fire resistance while they are resistant to } \\
\text { drought }\end{array}$ \\
\hline Ceanothus & California Lilac & $\begin{array}{l}\text { The colourful shrubs are both fireproof and tolerant to } \\
\text { drought }\end{array}$ \\
\hline Tulbaghia violacea & Society Garlic & $\begin{array}{l}\text { This plants grow in drought-prone regions and are safe to } \\
\text { fire }\end{array}$ \\
\hline Potentilla indica & $\begin{array}{l}\text { Ornamental } \\
\text { Strawberry }\end{array}$ & This plants are fireproof and used to provide lush cover \\
\hline $\begin{array}{l}\text { Delosperma } \\
\text { nubigenum }\end{array}$ & Yellow Ice Plant & $\begin{array}{l}\text { The terrain with succulent Green Foliage is very small } \\
\text { growing. This succulent requires minimal watering and fire } \\
\text { safe. }\end{array}$ \\
\hline $\begin{array}{l}\text { Coreopsis } \\
\text { lanceolata }\end{array}$ & Coreopsis & The plants are safe from fire. \\
\hline Cercis occidentalis & $\begin{array}{l}\text { California Red } \\
\text { Bud }\end{array}$ & Such fun bubbles are also fireproof and resistant to drought \\
\hline
\end{tabular}

\subsection{Australia:}

The home ignition area is responsible for inflammable items on and around the property. This includes items such as trees, bushes, ornamental beds, grass, adjacent houses, decks, closed areas and firewood products capable of combustion and firewood [20]. The domestic ignition area also includes the construction materials particularly wooden shingles, arch, balcony or overhanging eaves, vinyl soffits, and adjacent boarding and closed ceilings [21]. Building construction materials play an essential role in fire incidents. There is three typical scenarios for happening fire incidents: firebrands or embers, direct fire contact, and heat. Burning trees or buildings that can land and ignite inflammable materials are firebrands [20]. The effects of a dry cedar shingle are only found in a single 50-meter ember and it was developed that airflow and the capture of firebrands in small cracks were crucial to inflammation. The critical ignition angle of the fuel bed is between 90 and 135 degrees based on ignition tests [22]. 
Likewise, sparkling heat can damage materials that may be exposed to potential ignition by other flammable materials [21]. A burning shrub with one-pane glass outside a vinyl window will cause the window to break down or melt so that burns may enter the house, increasing the risk of fire. A homeowner must remove the ignition potential and disrupt the fire path in the approach of his house, hence minimisation of the possibility of domestic ignition [20].

In one of the studies, it is recommended to keep at least $9.1 \mathrm{~m}$ (30 feet) distance from natural vegetation in surface level and more than $30.5 \mathrm{~m}$ (100 feet) for house gradient [23]. Removing all plants and vegetations from the property yard is not required [20]. Ornamental plants should be separated in the non-burning area like managed grass. Trees should be planted in the sprayed way and not overlapped as well as dead plants and logs must be removed as soon as possible from housing area for reduction of fire ladder (Long and Randall 2004). Ornamentation materials for flower beds and plants should be fire resistance [24]. Plants with low flammability can be placed 1.5 $\mathrm{m}$ from the house in beds [20]. In other terms, a homeowner may build an esthetically pleasing landscaped yard but must be mindful that it only takes one weak point to ignite during a wildland fire [21]. More than $50 \%$ of buildings have been ignited within 3 hours after the city reaches the main fire front; $67 \%$ of homes were directly or indirectly ignited with brass; In contrast to $25 \%$ in the town, 40 per cent of demolished buildings were in the perimeter; and defensive measures have reduced losses from more than $37 \%$ to $30 \%$ [25]. Fire-resistant plants must have delicate and moist [26]. Plants that contain dead timber or log never dry and remove. The sapphire is waterlike and has no strong smell. The content of sap or resin is small.

Table 2: Some suggested fire-resistant deciduous trees and shrubs are listed below [26]. Groundcovers:

\begin{tabular}{ccc}
\hline Scientific Name & Common Name & Description \\
\hline Ajuga reptans & Carpet bugleweed & $\begin{array}{c}\text { It is a herbaceous flowering plant originating in } \\
\text { Europe, in the mint family. It is primarily cultivated } \\
\text { for its black, violet, dark green and multi-coloured } \\
\text { foliage. In early summer flower spikes grow above the } \\
\text { leaves. }\end{array}$ \\
\hline Aubrieta deltoidea & Rockcress & $\begin{array}{c}\text { Matting, perennial stretching with greyish-green } \\
\text { leaves. Attractive masses of flowers in spring. }\end{array}$ \\
& Pink pussytoes & $\begin{array}{c}\text { A beautiful floor covering with silver-grey leaf and } \\
\text { small flowers. Can be used in rocky gardens and } \\
\end{array}$ \\
& & between paving stones. \\
\hline
\end{tabular}

Perennials:

\begin{tabular}{ccc}
\hline Scientific Name & Common Name & Description \\
\hline Achillea millefolium & Yarrow & It has been introduced as a feed for livestock in places \\
& & like New Zealand and Australia. It's leaves in green to \\
& grey shades. Blossoming and highly resistant to \\
\hline
\end{tabular}


drought. Make a nice cut or dried flowers. Can be invasive.

\begin{tabular}{|c|c|c|}
\hline $\begin{array}{l}\text { Allium } \\
\text { schoenoprasum }\end{array}$ & Chives & $\begin{array}{l}\text { A common herb with grassy leaves and their close } \\
\text { relatives are onions, garlic, shallot, leek, scallion, and } \\
\text { Chinese onion. Reducing flowers when blooming is } \\
\text { over. }\end{array}$ \\
\hline Armeria maritima & Sea thrift & $\begin{array}{l}\text { A perennial clump with grassy foliage. Flowers of } \\
\text { rosy }\end{array}$ \\
\hline & & or white pompom flowers grow above the mound. \\
\hline
\end{tabular}

Shrubs-broadleaf evergreen:

\begin{tabular}{|c|c|c|}
\hline Scientific Name & Common Name & Description \\
\hline $\begin{array}{l}\text { Ceanothus } \\
\text { gloriosus }\end{array}$ & $\begin{array}{l}\text { Point Reyes } \\
\text { ceanothus }\end{array}$ & $\begin{array}{l}\text { It grows on the seaside bluffs and the coastal } \\
\text { mountain slopes. The inflorescence is a small cluster of } \\
\text { bright blue to purple flowers and leaves are } 5 \\
\text { centimetres long, rounded to oval in shape. Short- } \\
\text { lived (5-10 years) and wind-protective plants and } \\
\text { varieties are available. }\end{array}$ \\
\hline $\begin{array}{l}\text { Cotoneaster } \\
\text { apiculatus }\end{array}$ & $\begin{array}{l}\text { Cranberry } \\
\text { cotoneaster }\end{array}$ & $\begin{array}{l}\text { A semi-green broadleaf. Dark, bright, green leaves, in } \\
\text { the fall, becoming burgundy. Interesting growth } \\
\text { pattern. It produces little pink flowers and a red fruit } \\
\text { like cranberry which lasts in winter. Eastern exposure } \\
\text { is best. }\end{array}$ \\
\hline Cistus purpureus & $\begin{array}{c}\text { Purple-Flowered } \\
\text { Rock Rose }\end{array}$ & $\begin{array}{l}\text { It is a small, bushy evergreen shrub with large, } \\
\text { yellow-centred, purplish-pink flowers. Drought and } \\
\text { salt tolerant and protect from cold winds. Great for } \\
\text { slopes, borders, ground-covers, cottage gardens. }\end{array}$ \\
\hline \multicolumn{3}{|l|}{ Shrubs-deciduous: } \\
\hline Scientific Name & Common Name & Description \\
\hline Acer circinatum & Vine maple & $\begin{array}{l}\text { Native to western North America, from southwest } \\
\text { British Columbia to northern California with an } \\
\text { attractive red, orange to yellow drop habits. }\end{array}$ \\
\hline Amelanchier species & Serviceberry & $\begin{array}{l}\text { A shrub or tree multi-spring, with White flowers and } \\
\text { edible, purplish-black fruit Spring. } \\
\text { Outstanding red-orange fall colours prefers added } \\
\text { humidity. }\end{array}$ \\
\hline Acer glabrum & $\begin{array}{c}\text { Rocky Mountain } \\
\text { maple }\end{array}$ & $\begin{array}{l}\text { The leaves are } 2-10 \text { centimetres (0.79-3.94 in) broad, } \\
\text { three-lobed (rarely five-lobed) with a lovely green and } \\
\text { red foliage. During the summer, the seeds turn } \\
\text { reddish. Classy colour red drop. }\end{array}$ \\
\hline
\end{tabular}


Trees-conifer:

\begin{tabular}{|c|c|c|}
\hline Scientific Name & Common Name & Description \\
\hline Larix occidentalis & Western larch & $\begin{array}{l}\text { It is a large deciduous, coniferous tree reaching } 30 \text { to } \\
60 \text { metres ( } 98 \text { to } 197 \mathrm{ft} \text { ) tall. The crown is narrow conic } \\
\text { and leaves are needle-like, light green and long. They } \\
\text { turn bright yellow in the fall and pale orange-brown } \\
\text { until the next spring. }\end{array}$ \\
\hline Pinus ponderosa & Ponderosa pine & $\begin{array}{l}\text { Wonders pine tree in groups of two or three with long } \\
\text { green needles. The habit of growth is opened up with } \\
\text { age. The bark and cinnamon-brown bark colour are } \\
\text { fascinating. }\end{array}$ \\
\hline Acer ginnala & Amur maple & $\begin{array}{l}\text { It is a deciduous spreading shrub or small tree } \\
\text { growing to } 3-10 \mathrm{~m} \text { tall. The leaves turn bright orange } \\
\text { to red colour in autumn often pink-tinged. It is } \\
\text { suitable for more miniature landscapes to create a } \\
\text { hedge. }\end{array}$ \\
\hline
\end{tabular}

\subsection{Canada:}

In Canada, the Home Ignition Zone (HIZ) defines approximately 30-45 meter surroundings from the structure [27]. Three priority zones are identified by the Fire Smart program to control wildfire risk. The most important of target areas $1(10 \mathrm{~m})$ and $2(30 \mathrm{~m})$ are the Home Ignition Area (HIZ). Most notably, building design and its construction materials, surrounding landscape and designs are critical factors for surviving wildfire in a residential area. So, selecting landscape design and building materials should be given the highest priority to minimise fire-risk. In that case, a pre-planned landscape like water-smart design must be helpful in a functional way. The HIZ consists of three regions [19]:

a) Immediate Zone [19]:

The immediate zone means the nearest region particularly from the starting point from $0-5^{\prime}$ surroundings of home. It must be ensured that this zone always fuel-free because it contains high risk. Regular cleaning roofs and gutters are very important because retaining dead leaves, debris and pine needles increase the chance to ember. Damages or any missing shingles or roof tiles can create a path to catch up the fire inside the house, so a new one must substitute it. The aesthetic and precaution value will be increased by exchanging or adding a new one.

On the other hand, decreasing charcoal that can move through the vents by adding a 1/8 "mesh screen. Debris from roof ventilation windows must be swept and installed 1/8 inch metal screen fabric to minimise embers. After the installation of wire mesh, regular monitoring on window screens and box-in areas below patios and decks should be conducted and take quick actions in damage occurrence. It can prevent accumulations of combustible materials and debris. To keep safe house, remove any kind of flammable materials away from outside walls, firewood piles and material which 
can burn flammable plants, leaves and needles. The portion of beneath decks or porches must be free from everything.

b) Intermediate Zone [19]:

The intermediate zone is mainly next to the immediate zone. It levels the outermost point from house and range between 5-30'. Major precautions must be taken for this portion for reducing or avoiding fire accidents. First of all, the underneath place of wide stationary propane tanks must be cleared and not to use for vegetation. Trees placement should be designed to keep a safe distance (at least 10' away from the edge of the house) for mature canopy (National Fire Protection Association 2018). Spaces between the canopy trees depend on two factors: slope and crown size. Minimum eighteen feet distance should be kept between the crowns and it will be increased with the percentage of slope. For continuous green landscape, small clusters should be made up both for trees and shrubs in this intermediate zone. Native grasses height is not more than four inches in the lawn area. Vegetation under trees may treat as a ladder to reach fire at the crown. So, trim trees if its height exceeds 6-8 feet from the ground and not more than $1 / 3$ of the total tree height for shorter trees. Driveways, walkways or paths, patios, and decks must be free from all kind of fuels.

c) Extended Zone [19]:

Extended zone limits mainly from 30 to 100 feet, a maximum of 200 feet in some cases. The primary purposes are not to abolish fire but make an interruption of fire's path and dominate fire flames smaller on the ground. So, the extended zone requires some specific landscape design. At least 6 feet distances between canopy crowns must be maintained for trees in 60-100 feet from the house.

Additionally, the crown distance must be double from previously mentioned measurement for trees in 30-60 feet from the house. Small conifers, dead plants and dry tree materials between two mature trees must be cleaned up and do not accumulate all collected debris near outer buildings or storage sheds. It must be ensured of proper disposal of this waste.

According to "FireSmart Guideline, Canada", some common characteristics of fire-resistant plants are [28]:

- Containing moist, flexible leaves

- Small deadwood and a propensity to not store dead content

- The water-like fluid which circulates in the vascular system of plants with little or no odour

- Low amount of plant fluids or resin material

It is necessary to make the assurance that the selected plants are appropriate to the region and hardiness zone when selecting landscape plants.

Table 3: Suggested trees:

\begin{tabular}{ccc}
\hline Scientific Name & $\begin{array}{c}\text { Common } \\
\text { name }\end{array}$ & Descriptions \\
\hline Acer ginnala & Amur Maple & Same as above (see Table 2: Trees conifers) \\
\hline Acer & Bigleaf Maple & $\begin{array}{r}\text { The largest leaves of any maple, typically } 15-30 \mathrm{~cm} \text {, The } \\
\text { leaves turn to gold and yellow in the fall, frequently }\end{array}$ \\
\hline macrophyllum & &
\end{tabular}


creating a stunning effect against the backdrop of evergreen conifers

\begin{tabular}{|c|c|c|}
\hline Acer palmatum & $\begin{array}{l}\text { Japanese } \\
\text { Maple }\end{array}$ & $\begin{array}{l}\text { A large variety of attractive forms, leaf shapes, and } \\
\text { spectacular colours. Crown often shapes on a dome-like } \\
\text { form, especially when mature }\end{array}$ \\
\hline \multicolumn{3}{|l|}{ Suggested Shrubs: } \\
\hline Scientific Name & $\begin{array}{l}\text { Common } \\
\text { name }\end{array}$ & Descriptions \\
\hline Berberis sp. & Barberry & $\begin{array}{l}\text { A large genus of deciduous and evergreen shrubs, used as } \\
\text { food plants. }\end{array}$ \\
\hline Buddleia sp. & Butterfly Bush & $\begin{array}{l}16 \mathrm{ft} \text { tall, leaves are lanceolate and flower mainly pinks and } \\
\text { blues colour. }\end{array}$ \\
\hline Caluna vulgaris & Heather & $\begin{array}{l}\text { Low evergreen shrub, widespread in western Europe and } \\
\text { Asia, North America, and Greenland. }\end{array}$ \\
\hline \multicolumn{3}{|c|}{ Suggested Vines and Groundcover: } \\
\hline Scientific Name & Common name & Descriptions \\
\hline Ajuga reptans & Carpet Bugle & Same as above (see Table 2: Groundcovers) \\
\hline Antennaria rosea & Pussytoes & Same as above (see Table 2: Groundcovers) \\
\hline $\begin{array}{l}\text { Arctostaphylos } \\
\text { uva-ursi }\end{array}$ & Kinnickinnick & $\begin{array}{c}\text { small procumbent woody ground cover shrub, The leaves } \\
\text { are evergreen, and they stay green } 1-3 \text { years before } \\
\text { dropping. The fruit is a red berry }\end{array}$ \\
\hline
\end{tabular}

Suggested Grasses:

\begin{tabular}{|c|c|c|}
\hline Scientific Name & Common name & Descriptions \\
\hline Agropyron & Wheatgrass, & densely tufted grass, culms ranges from $30-50 \mathrm{~cm}$ high \\
\hline cristatum & Crested, Western & with spike and spikes range from $2-7 \mathrm{~cm}$ long. Found \\
\hline & & everywhere in the United States and Canada. \\
\hline \multirow[t]{3}{*}{ Bouteloua gracilis } & Mosquito Grass, & Commonly found in Alberta, Canada. Long-lived green \\
\hline & Blue Grama Grass & or greyish, low-growing, drought-tolerant grass with \\
\hline & & limited maintenance. \\
\hline
\end{tabular}

Buchloe Buffalo grass Drought, heat, and cold-resistant perennial shortgrass.

dactyloides

Foliage usually 5-13 cm high. Native to Canada, Mexico, and the United States.

\begin{tabular}{ccc}
\hline \multicolumn{2}{l}{ Suggested Perennials and Biennials: } \\
\hline Scientific Name & Common name & Descriptions \\
\hline Achillea sp. & Yarrow & Same as above (see Table 2: Perennials) \\
\hline Alcea rosea & Hollyhock & Ornamental plant - flowers colour range from white to \\
& & dark red, including pink, yellow and orange.
\end{tabular}




\begin{tabular}{|c|c|c|}
\hline $\begin{array}{c}\text { Anaphalis } \\
\text { margaritacea }\end{array}$ & Pearly Everlasting & $\begin{array}{l}\text { Commonly found in the United States and Canada. } \\
\text { Leaves are covered in tiny hairs, yellowish flower and it } \\
\text { prefers dry, sunny climates. }\end{array}$ \\
\hline \multicolumn{3}{|l|}{ Suggested Annuals: } \\
\hline Scientific Name & Common name & Descriptions \\
\hline $\begin{array}{c}\text { Antirrhinum } \\
\text { majus }\end{array}$ & Snapdragon & $\begin{array}{l}\text { An ornamental plant-herbaceous perennial plant } \\
\text { usually cultivated once a year. Leaves are 1-7 cm long. } \\
\text { Pink to purple flowers, often with yellow lips. }\end{array}$ \\
\hline Gazania ringens & Gazania & $\begin{array}{l}\text { Sometimes called treasure flower. } 50 \mathrm{~cm} \text { tall and wide, } \\
\text { with blue-grey foliage and yellowish flowers in } \\
\text { summer. }\end{array}$ \\
\hline Geranium sp. & Geranium & $\begin{array}{l}\text { Long, palmately cleft leaves. White, pink, purple or } \\
\text { blue colour flowers. Found throughout the temperate } \\
\text { regions. }\end{array}$ \\
\hline \multicolumn{3}{|l|}{ Suggested Bulbs: } \\
\hline Scientific Name & Common name & Descriptions \\
\hline Allium cernum & Nodding Onion & $\begin{array}{l}\text { grows in dry woods, rock outcroppings, and prairies. } \\
\text { Unsheathed slender conical bulb, grass-like leaves } 2-4 \\
\text { mm. Nodding umbel of white or rose flowers. }\end{array}$ \\
\hline Crocus sp. & Crocus & Flowers appearing in autumn, winter, or spring \\
\hline Lilium sp. & Lily & $\begin{array}{l}\text { herbaceous flowering plants, height from 2-6 ft. Flowers } \\
\text { are large, often fragrant and wide range of colours } \\
\text { including whites, yellows, oranges, pinks, reds and } \\
\text { purples. }\end{array}$ \\
\hline
\end{tabular}

Suggested Building Materials:

- $\quad$ Stone, Masonry, and Concrete:

Building materials that can effectively withstand fire, particularly wildfires, are stone, masonry (fabricating in stone, clay, brick, or concrete block) and concrete, as typically they are extinguished when the fuel has been consumed. These three materials alone or combined would be perfect for a well wrapping for the house for defending wildfire. One storeyed building can get well protection from these three materials.

- Structural Steel and Metals:

Once steel exceeds its critical temperature, the fire loses its carrying capacity (i.e. the temperature at which it fails to support its load). In general, steel is used mainly for building interior structure same as aluminium is used for non-structural components like window or door frames. Aluminium has an extremely low melting point in comparison to steel, loses any structural properties easily when exposed to heat and cannot resist wildfire forces. That's why it is not recommended that the use of a certain aluminium wall [29]. 


\section{- Heavy Timber Construction:}

Canadian Wood Council reported that large sections of wood have an intrinsic fire resistance power. According to Morrison Hershfield Team, these large section wood burns slowly at approximately $0.6 \mathrm{~mm} / \mathrm{minute}$. When fuel can not be avoided, heavy wood construction can be considered to create a building structure against fire occurrences [29].

Discussion: Wildfire like a curse in some region of the world. It can play a devastative role for humans, plants, animals and assets. Quick eradication process has not developed yet. Once a fire occurs, it can turn a rich biodiversity land into barren land. The behaviour and severity of wildfires result from a combination of factors such as available fuels, physical setting and weather. Controlled burning is one common and inexpensive technique. In fire-prone areas, some precautions are required to follow minimizing losses. In this article, we have discussed about the prescribed defensible zone in a different country, effective landscape changing, selecting appropriate building materials and list of fire-resistance plants that can help reducing fire flames or embers.

Conflicts of Interest: The authors declare no conflict of interest.

\section{References}

1. Radeloff, V.C.; Hammer, R.B.; Stewart, S.I.; Fried, J.S.; Holcomb, S.S.; McKeefry, J.F. The wildland-urban interface in the United States. Ecological applications 2005, 15, 799-805.

2. Verisk. Wildland-urban interface risks are increasing. Available online: https://www.verisk.com/insurance/visualize/wildland-urban-interface-risks-are-increasing/(accessed on 6 October).

3. USDA. A Look at Life in the Wildland Urban Interface. Available online: https://www.usda.gov/media/blog/2015/10/27/look-life-wildland-urban-interface (accessed on 6 October).

4. Radeloff, V.C.; Helmers, D.P.; Kramer, H.A.; Mockrin, M.H.; Alexandre, P.M.; Bar-Massada, A.; Butsic, V.; Hawbaker, T.J.; Martinuzzi, S.; Syphard, A.D. Rapid growth of the US wildland-urban interface raises wildfire risk. Proceedings of the National Academy of Sciences 2018, 115, 3314-3319.

5. Rahman, S.; Chang, H.C.; Magill, C.; Tomkins, K.; Hehir, W. Forest Fire Occurrence and Modeling in Southeastern Australia. In Forest Fire, InTech: 2018; p. 151.

6. Rahman, S. Determining the Impact of Fire Severity on Vegetation Regrowth As a Result of the Greek Forest Fires 2007. University of Southampton, 2014.

7. EPS. A Profile of Development and the Wildland-Urban Interface (WUI); Economic Profile System (EPS), Headwaters Economics: Montana, USA, 2015.

8. Stewart, S.I.; Radeloff, V.C.; Hammer, R.B. Characteristics and location of the wildland-urban interface in the United States. In Proceedings of 2 nd International Wildland wildfire Ecology and wildfire Management Congress. Orlando, Florida.

9. Rahman, S.; Chang, H.-C.; Hehir, W.; Magilli, C.; Tomkins, K. Inter-Comparison of Fire Severity Indices from Moderate (Modis) and Moderate-To-High Spatial Resolution (Landsat 8 \& Sentinel-2A) Satellite Sensors. In Proceedings of IGARSS 2018-2018 IEEE International Geoscience and Remote Sensing Symposium; pp. 2873-2876. 
10. Rahman, S.; Chang, H.-C. Assessment of fire severity and vegetation response using moderate-resolution imaging spectroradiometer: Moderate-resolution (MODIS) satellite images to assess vegetation response after a big fire event at the selected national parks around Sydney, Australia. In Proceedings of Sensing Technology (ICST), 2017 Eleventh International Conference on; pp. 1-6.

11. Johnston, L.M.; Flannigan, M.D. Mapping Canadian wildland fire interface areas. International journal of wildland fire 2018, 27, 1-14.

12. IAFC. The Ready, Set, Go! . Available online: http://www.wildlandfirersg.org/About/Wildland-UrbanInterface (accessed on 9 September).

13. USDI. Wildland Fire - Learning In Depth. Available online: https://www.nps.gov/articles/series.htm?id=ED398874-1DD8-B71B-0B594AA554EB0E8C (accessed on 2 October).

14. NIFC. Wildland Fire Statistics. Available online: https://www.nifc.gov (accessed on 2 October).

15. WUIMC. Wildland-Urban Interface Wildfire Mitigation Desk Reference Guide; Wildland Urban Interface Mitigation Committee (WUIMC), The National Wildfire Coordinating Group: 2017.

16. FEMA. Home Builder's Guide to Construction in Wildfire Zones. (FEMA), F.E.M.A., Ed. 2008.

17. FireSafe. Defensible Space. Available online: https://www.firesafesanmateo.org/resources/defensible-space (accessed on 8 October).

18. CALFIRE. Prepare for Wildfire. Available online: http://www.readyforwildfire.org/Defensible-Space/ (accessed on 8 October).

19. NFPA. Home Ignition Zone. Available online: http://www.riverplacehoa.org/wp-content/uploads/HOMEIGNITION-ZONE.pdf (accessed on 6 October).

20. Mercer, D.E.; Zipperer, W. Fire in the wildland-urban interface. Urban-rural interfaces: Linking people and nature 2012, 287-303.

21. Doran, J.D.; Randall, C.K.; Long, A.J. Fire in the wildland-urban interface: Selecting and maintaining firewise plants for landscaping. Gainesville, FL: University of Florida, Institute of Food and Agricultural Sciences; USDA Forest Service, Southern Research Station, Southern Center for Wildland-Urban Interface Research and Information. 7 p. 2004.

22. Manzello, S.L.; Park, S.-H.; Cleary, T.G. Investigation on the ability of glowing firebrands deposited within crevices to ignite common building materials. Fire Safety Journal 2009, 44, 894-900.

23. Cohen, J.D. What is the wildland fire threat to homes? Thompson Memorial Lecture, School of Forestry, Northern Arizona University, Flagstaff, AZ, 10 April 2000. 2000.

24. White, R.H.; Zipperer, W.C. Testing and classification of individual plants for fire behaviour: plant selection for the wildland-urban interface. International Journal of Wildland Fire 2010, 19, 213-227.

25. Mell, W.E.; Manzello, S.L.; Maranghides, A.; Butry, D.; Rehm, R.G. The wildland-urban interface fire problem-current approaches and research needs. International Journal of Wildland Fire 2010, 19, 238-251.

26. Detweiler, A.J.; Fitzgerald, S.A. Fire-resistant plants for home landscapes: Selecting plants that may reduce your risk from wildfire. 2006.

27. Cohen, J.D.; Johnson, N.; Walther, L. Saving homes from wildfires: regulating the Home Ignition Zone; National Emergency Training Center: 2001. 
28. FireSmart. FireSmart Guide to Landscaping; Government of Alberta, Canada: 2016.

29. AI. Guideline for Wildfire Protection of Institutional Buildings in Forested Regions in Alberta; Technical Services Branch, Alberta Infrastructure (AI): 2013. 